University of Nebraska - Lincoln

DigitalCommons@University of Nebraska - Lincoln

Spring 1985

Having A Purpose In Life Western Women Teachers In The Twentieth Century

Courtney Ann Vaughn-Roberson

University of Oklahoma

Follow this and additional works at: https://digitalcommons.unl.edu/greatplainsquarterly

Part of the Other International and Area Studies Commons

Vaughn-Roberson, Courtney Ann, "Having A Purpose In Life Western Women Teachers In The Twentieth Century" (1985). Great Plains Quarterly. 1849.

https://digitalcommons.unl.edu/greatplainsquarterly/1849

This Article is brought to you for free and open access by the Great Plains Studies, Center for at DigitalCommons@University of Nebraska - Lincoln. It has been accepted for inclusion in Great Plains Quarterly by an authorized administrator of DigitalCommons@University of Nebraska - Lincoln. 


\title{
HAVING A PURPOSE IN LIFE \\ WESTERN WOMEN TEACHERS IN THE \\ TWENTIETH CENTURY
}

\author{
COURTNEY ANN VAUGHN-ROBERSON
}

Beginning late in the eighteenth century, social theorists developed an ideology of domesticity, maintaining that women's proper role lay in the care of children, the nurture of the husband, the physical maintenance of the domicile, and the guardianship of both home and social morality. ${ }^{1}$ Although this ideology helped to propel females in to teaching, historians have not agreed on the impact of domestic ideology on women teachers and on the education profession itself. Some scholars conclude that women's easy access to teaching posts turned the classroom into a workshop for motherhood for the average female, perpetuating anti-intellectualism in education to the present day. ${ }^{2}$ Other research, focusing on women who dedicated themselves to teaching during the nineteenth and early twentieth centuries, portrays them as highly professional. ${ }^{3}$ A few studies seem to bridge the

Courtney Ann Vaughn-Roberson is assistant professor of foundations in the College of Education of the University of Oklahoma. Her writings on Oklahoma teachers have appeared in such journals as Pacific Historical Review.

[GPQ 5 (Spring 1985): 107-24.] gap between those contradictory views, highlighting both the professional opportunities and the behavioral restrictions that domestic ideology provided to women teachers and to other women whose careers were and still are defined by the traditional women's role. ${ }^{4}$

This paper depicts 547 western women teachers, most of whom were born during the first decade of the twentieth century, who developed their own personal and professional variations on the traditional ideology of domesticity, an ideology that seemed to them to give their work meaning and purpose. Although changing social conditions and personal experiences encouraged them to emphasize varying interpretations of the domestic role during their lives, these teachers have remained firmly entrenched within the traditional female sphere, and it is from there that they have observed the world and judged themselves.

\section{DESCRIPTION OF SUBJECTS}

Because most published historical studies of female educators do not deal with the twentieth century, I began in 1980 to locate subjects for a study that would test earlier scholars' observations on the importance of domestic 
ideology for women teachers by evaluating the significance of domesticity in the lives of a new era of career-oriented women. If the traditional belief had survived as part of their vocational and personal value system, then its potency as a social force would be documented well into the current century. Moreover, I could trace the historical and social reasons for this potence despite the paradoxes inherent in using the idea of domesticity to show women's increased involvement in gainful employment outside the home. Thus my search centered around professional associations and other organizations likely to include women who had taught for many years. My end product was a large body of reminiscences, letters, personal interviews, and biographical sketches of 547 women teachers from three western states-Oklahoma, Texas, and Colorado.

The Oklahoma Retired Teachers Association in the mid-1970s had written to its members asking each to "tell her or his story" and had been rewarded with a wealth of material. ${ }^{5}$ From seven volumes of that correspondence I found 214 women teachers of the appropriate age to form the nucleus of this study. They were all of predominantly white ancestry, although a few reported partial Indian descent. Even those "mixed-bloods," however, were patriotic Protestants who identified with the dominant society. I obtained additional information on 47 of the 214 teachers by writing to them myself. Their responses contained such demographic information as degrees held, marital status, and place of birth. Respondents also explained why they had selected careers in education, how supportive their families had been, what constituted their own educations, and what they held to be acceptable male and female behavior. I contacted another 104 teachers by mail and interviewed 3 more, having obtained all of their names from fellow teachers. In Oklahoma I also located 25 black teachers, and 3 full-blood Indian educators, but because many professional groups (my major source of contacts) initially excluded minority members, my sample size for the tri-state region was so small that I omitted any separate analysis of those teachers. ${ }^{6}$
In Texas, a state contiguous to but more southern in character than Oklahoma, I contacted sixty-three women teachers, most of whose names I found on the membership lists of Delta Kappa Gamma, an organization of women educators founded in 1929. Personalities, a work of paraphrased interviews with selected state members published in 1980 by the Texas Iota chapter of Delta Kappa Gamma, contributed twenty-seven more subjects. A series about notable Texas women, run in the Amarillo Daily News, added another seven teachers; and citations from these articles led to the work of two more female educatorsLight 'n' Hitch, by Laura Hammers, and A Pioneer Farmer's Daughter of the Red River Valley, by Emma Bourne. Finally, I conducted one personal interview, and then the entire list totalled ninety-nine Texas teachers.

In an attempt to maintain some geographical consistency while obtaining subjects from a more liberally-oriented western state, I contacted forty-three Colorado women teachers, again gleaning names from the Delta Kappa Gamma rolls. Torchbearers, a 1967 publication about key women teachers in that organization, contained an additional forty-eight Colorado women appropriate for this study, and manuscript material originally gathered for the book but not published offered information on eleven more. I found the remainder of my Colorado teachers among the subjects of oral history interviews conducted largely by the state's county library personnel and catalogued at the Denver Public Library Western History Collection. One more I found through an article in Colorado Magazine, and one I interviewed.

My final sample, then, consisted of professionally minded women teachers from each state who had spent twenty to fifty-five years on the job. Moreover, 85 percent of them hailed from small towns or rural areas, pervaded with traditional American values including conservative views of women's roles. These were women who felt a sense of consistency and purpose despite the complexity involved in trying to reconcile the contradictory messages of domestic ideology. 


\section{HISTORY, DOMESTIC IDEOLOGY, AND WOMEN TEACHERS}

Domesticity's rich heritage in American educational thought makes perfectly understandable its persistence well into the twentieth century. During the American Revolution, progressive social theorists first popularized the notion that the new nation's mothers had a patriotic duty to rear morally sound and literate children. Advocates of women's education such as Benjamin Rush and Sarah Pierce reasoned that the new country's women should be molded for Republican Motherhood-the rearing of patriotic, ethical, and knowledgeable children. ${ }^{7}$

As the self-sufficient rural household gave way to an urban ideal of consumption, women's productive role declined, and their claims to influence rested ever more on their alleged ethical, emotional, and spiritual superiority. ${ }^{8}$ For the early-nineteenth-century woman, economically displaced by the emergence first of a commercial market and then by an urbanindustrial economy, caring for children and shaping their morals became the woman's paramount duty, sanctified by the domestic ideology. In the midst of growing class antagonism, urban disorder, and changes in the division of labor, a new generation of educators such as Catharine Beecher, Horace Mann, and Mary Lyon hoped women's pious and quiet influence over men and children would cure the ever-increasing social unrest. In their ideal society, gender, rooted in biology and hence unalterable, would be the only division. ${ }^{9}$ The celebration of male and female spheres had arrived but not without feminist opponents such as Margaret Fuller, who confided that after leaving teaching in 1838 , "she now hoped to do something good for women." 10 Despite such opponents, the "culture of professionalism" flourished, offering a separate set of careers to men and women, based on the assumption that males were mandated to manage and females to nurture. ${ }^{11}$

Female teachers, nurses, social workers, and volunteers, laboring in both sparsely populated and urban settings, greatly influenced the building of communities in the United States. ${ }^{12}$ Women followed the frontier across the North American continent, and many helped create new settlements, erecting churches and schools or staffing social service agencies. Though a few historians emphasize the role of domestic ideology in subordinating female pioneers to male authority, other scholars highlight the power and influence western women gained as community builders. ${ }^{13}$ Julie Roy Jeffrey, in an analysis of the trans-Mississippi frontier from 1840 to 1880 , and Mary Ryan, in a depiction of Oneida County, New York, from 1780 to 1865 , explain that women formed social institutions that were the agents of morality in the community. ${ }^{14}$ Although, according to Ryan, later generations of the more urbanized Oneida women spent more time within the new privatized home, the female sphere had already been extended and formalized beyond the domicile. Despite the many ways women's interests extended into the community, however, the school remained the primary institution for single women's professional gainful employment because dedicated teachers were always needed "to facilitate the passage of children out of the home and into society and the economy."15

More and more females responded to this need, until by 1888,63 percent of the nation's teachers were women. ${ }^{16}$ Western settlers seemed to show a special appreciation for women's roles in establishing and running schools. In 1838 , Kentucky, then a frontier state, initiated a novel experiment, granting women the right to vote in elections that concerned education. Although it was twenty-three years before another jurisdiction, Kansas, would grant the same right to its adult females, the Kansas action ignited a trend in the trans-Mississippi West, where thirteen other states and territories had implemented the measure by $1890 .{ }^{17}$ In 1893 , North Dakota became the first state to elect a female state superintendent of schools. By 1922 , nine western states had placed women in the educational chief executive's seat, the only females in the country to hold such positions. ${ }^{18}$ 


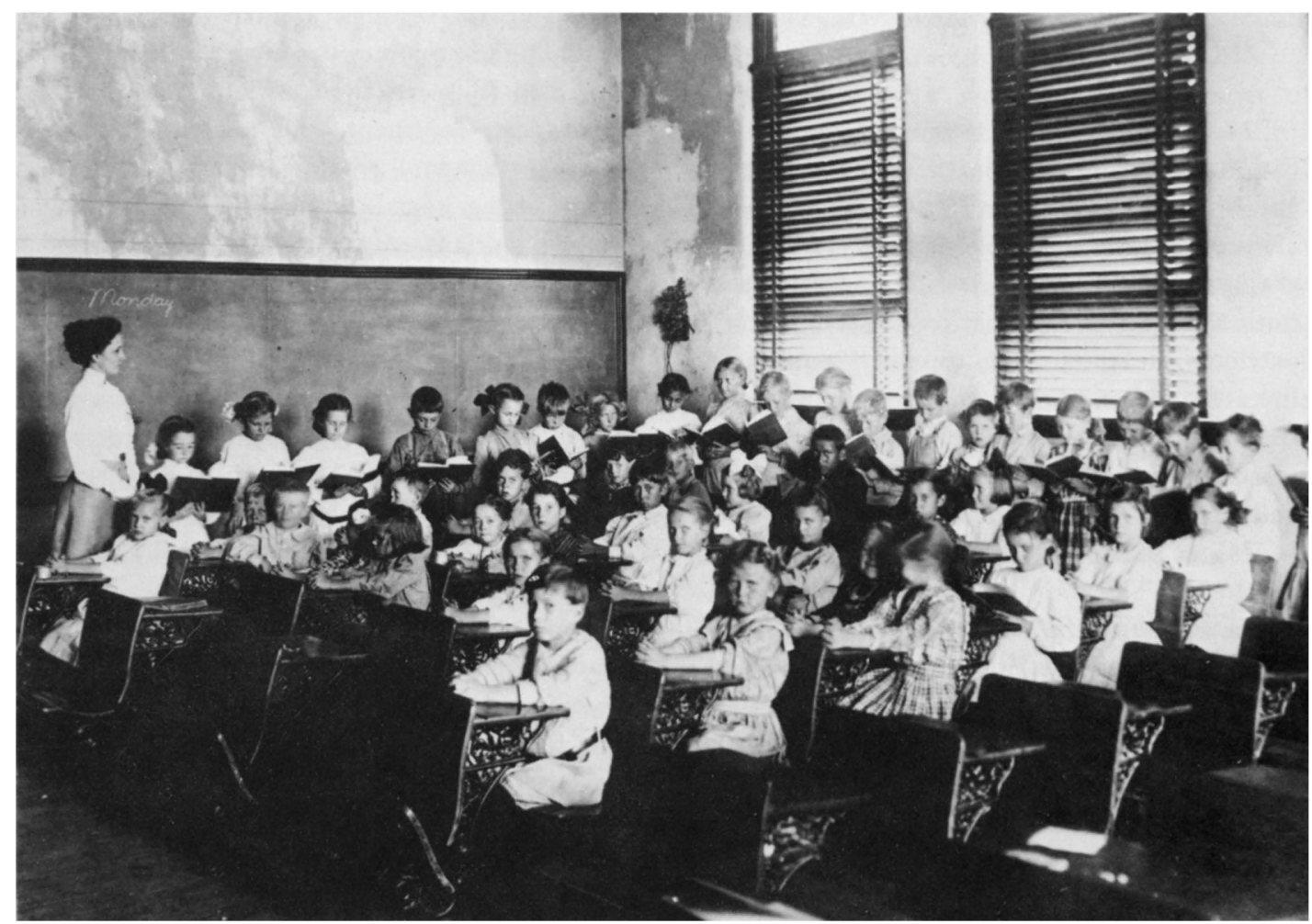

FIG. 1. Classroom, probably Oklahoma, no date. Western History Collections, University of Oklahoma Library.

Colorado women involved themselves in educational policy making during and after Reconstruction. With statehood in 1876, they won for themselves suffrage in school elections. Seventeen years later, marking a period of Populist ascendancy, Colorado males became the third group of voters in the country to approve the full franchise for adult females. ${ }^{19}$ Beginning in 1895, after J. F. Murray's term ended as Colorado state superintendent, the expanded state electorate consistently designated women to the position until 1952. Many of these administrators became known and respected in national education circles. Helen Grenfell, who held the post from 1898 to 1904 , in 1903 was elected the country's first female vice-president of the National Education Association (NEA), founded in $1857 .{ }^{20}$ (In 1909, the organization named Ella Flagg Young, Chicago city school superintendent, its first woman president.) ${ }^{21}$ Mary C. C. Bradford, a regional promoter for the national suffrage campaign, served as Colorado state superintendent from 1913 to 1921 and again from 1923 to $1927 .^{22}$ Willing to stretch the limits of domestic ideology in their day, neither Coloradan accepted the common notion that marriage and motherhood demanded that she relinquish her position. As Grenfell reasoned, education was part of the female domain, an "outgrowth of the home or ... the family's way of working out the best interests of the child." 23

Like their colleagues to the northwest, Oklahoma women educators actively reached for the political power to shape their social environment. In 1895 Oklahoma Territory sixthgrade teacher Margaret Rees founded the Oklahoma Equal Suffrage Association, and when 


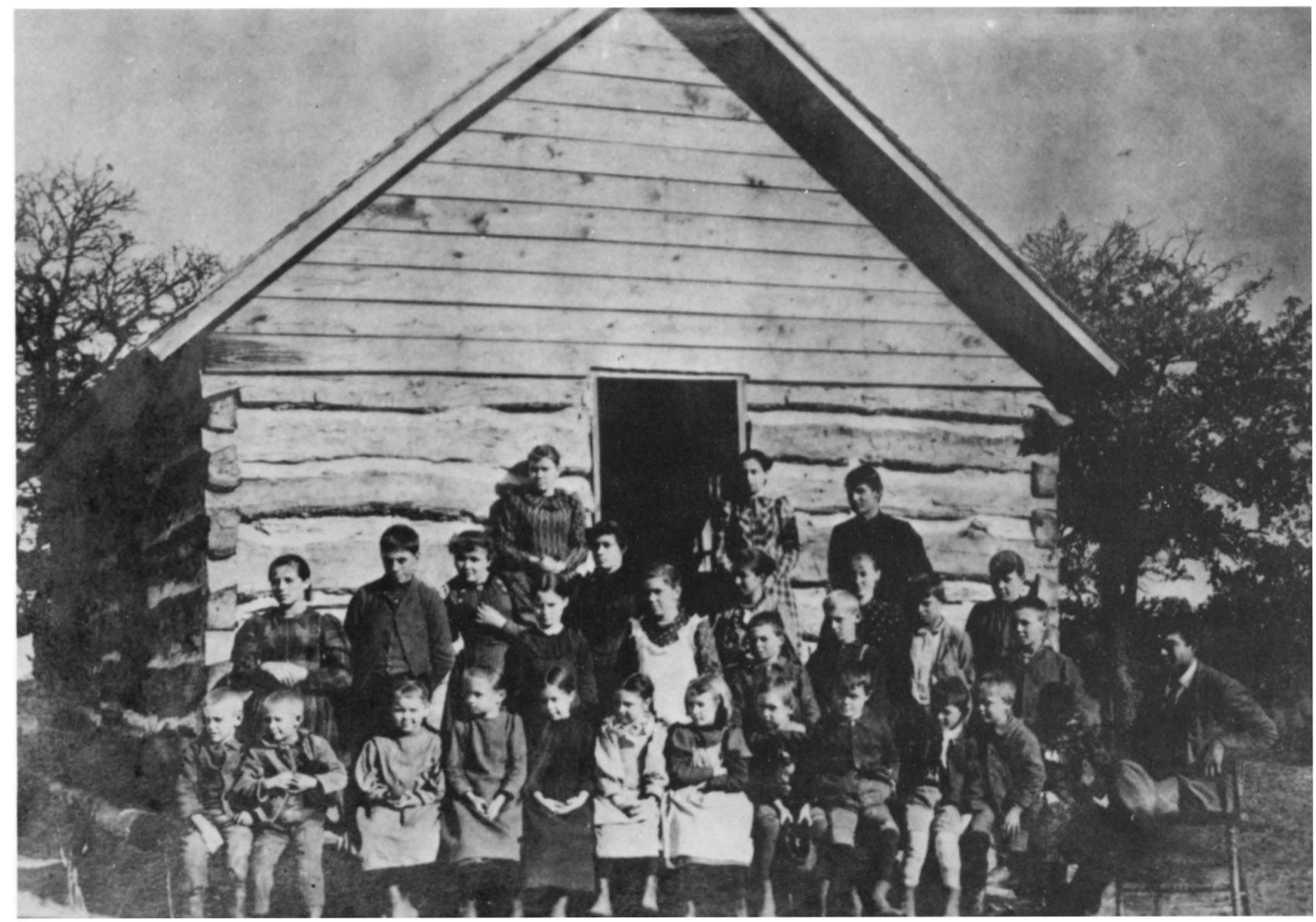

FIG. 2. Children and log school, probably Oklahoma, no date. Western History Collections, University of Oklahoma Library.

Oklahoma and Indian territories joined to become the state of Oklahoma in 1907, women obtained the vote in school-related elections. ${ }^{24}$ Even so, four years later a newly appointed state board of education put a ceiling on women's involvement in running schools, decreeing that "no person was eligible to the office [of state superintendent] except a male ... of more than thirty years of age." 25 Until the Nineteenth Amendment was ratified in 1920, white racism helped defeat the full suffrage issue in Oklahoma because many white citizens feared the potential for black power if that race of women could vote. ${ }^{26}$

Despite restrictions, Oklahoma women educators such as Indian Territory's Alice Robertson eventually gained state and nationwide recognition. Like hundreds of other nineteenthcentury teachers, Robertson was an ardent
Christian who sought to impart moral values and practical knowledge to both Indian and white children. She became a founder of the Indian Territory Teachers Association in 1884, and sixteen years later federal officials selected her superintendent of education for the Creek Nation. In 1905, two years after Grenfell had made history, Robertson became the NEA's next vice-president. By 1920 the Oklahoma Republican educator's popularity helped make her the country's second woman to serve as representative to the United States Congress. ${ }^{27}$ Though she had opposed woman suffrage, while serving Oklahoma in Washington, D.C., Robertson challenged her newly enfranchised sisters to continue spreading domestic values:

The American women, instead of standing aside and drawing their skirts about them 
piously, must now pitch in and work for the reforms they have been demanding. Women suffrage is like an automobile ride. When something goes wrong with the flivver and the man gets out to fix it, the woman in the back seat ought to either get out and help him or keep her mouth shut. ${ }^{28}$

Texas women also sought to broaden their social influence. The Texas Equal Rights Association was established in 1893 and reorganized twenty years later as the Texas Woman Suffrage Association. Also hampered by racism, it accomplished only the partial enfranchisement of women in 1918 when Texas males finally granted women suffrage in primary elections. A year later Texas suffragists supported in her successful bid for state superintendent of education Annie Webb Blanton, the only woman in the state ever to hold that position. ${ }^{29}$

Blanton held a doctorate from Cornell University and as superintendent worked to improve the credentials of all Texas teachers, but especially of women. In return for her demands on female educators, she lobbied for their equitable treatment on the job and for a non-genderbased pay scale throughout the state. ${ }^{30}$ In addition to being state superintendent from 1919 to 1923, Blanton served as president of the Texas State Teachers Association, founded in 1879, and was elected vice-president of the NEA on three separate occasions. ${ }^{31}$ In 1929 in Austin she and a handful of others founded Delta Kappa Gamma. Created initially for white female educators with impeccable credentials, its purpose was to provide money and encouragement for capable women teachers to work toward advanced degrees and to claim places as administrators in local schools. A few years later Oklahoma and Colorado formed their own chapters of Delta Kappa Gamma, which is today an integrated international society. Despite advances in female solidarity, neither Blanton nor most of her more labor-oriented sisters who were founding teachers' unions to the northeast overtly challenged the concept of separate spheres, using domesticity instead to argue for women's paramount position within the education profession. ${ }^{32}$ For example, in 1910 Grace Strachan, head of the New York Interborough Association of Women Teachers executive committee wrote, "I am firmly convinced that while teaching is a natural vocation for most women, it is rarely the true vocation of a man.",33

\section{TEACHER SOCIALIZATION}

\section{AND EDUCATION}

Although notable women educators were role models for girls coming of age during the early twentieth century, the women in this study were more strongly influenced in their initial career decisions by their own families and teachers. As a child, Coloradan Minnie Schroter strove to be like Marion, the schoolteacher next door, whom her parents greatly admired. "That girl is very intelligent," Schroter's father had said, and Minnie's mother had reiterated, "Indeed, she is, and what's more she is very pretty." 34 Christine Kirkpatrick's parents concurred with the Schroters that "teaching was the highest profession a young woman could pursue," while Opal Scales recounted that she and her sisters "became teachers because at that time teaching was considered the most desirable occupation for a young girl."35 Presenting a dramatic example of a parent's commitment to education, Allie Collin's mother pleaded with her father-in-law from her deathbed, " $\mathrm{Pa}$, promise me that my children will get an education"; for Allie such schooling led to a teaching career. ${ }^{36}$

To some parents preparing a daughter for teaching was an act of almost religious importance. Eleanor Reser remembers her father admonishing her to "sincerely commit myself to the child, community, and school and [to remember] that each individual child's future education depends on the foundation I could instill within him or her." Zelma Farris received the same encouragement, which led to her goal of "instill[ing] in the minds of our young Americans the art of living an honest and upright life that they might be able to take their place in this fast changing world as useful 


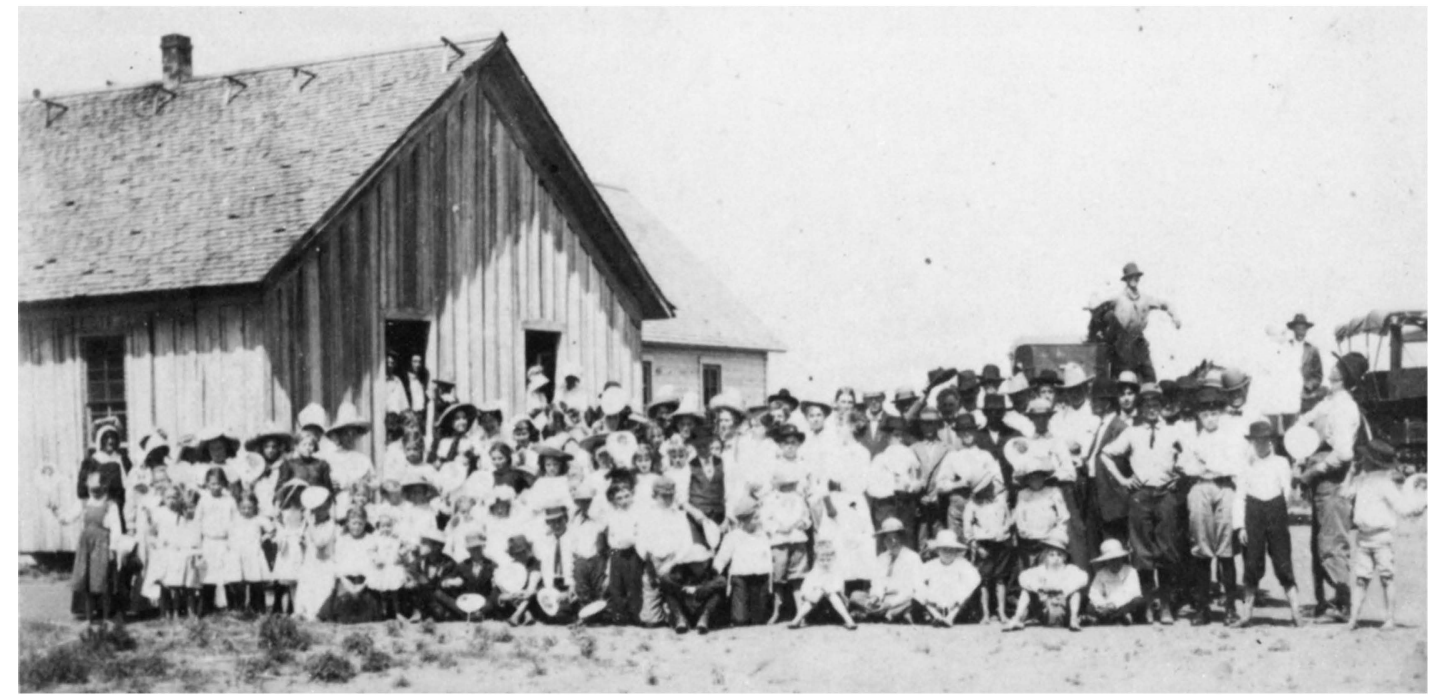

FIG. 3. Last day of school at Teacross, in Hollis, Oklahoma, 1910. Western History Collections, University of Oklahoma Library.

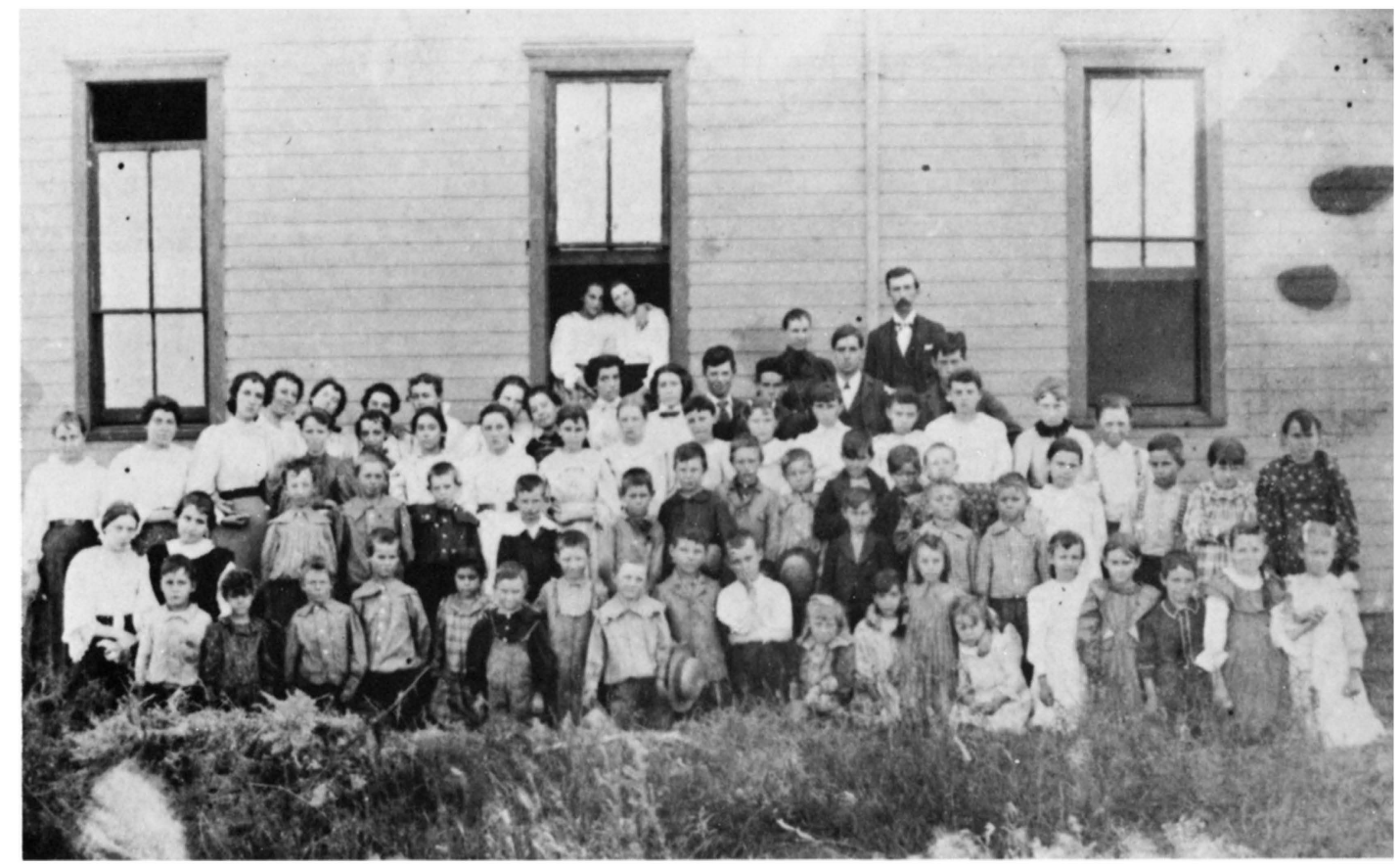

FIG. 4. Tonkawa, Oklahoma, school, with teachers Levi and Lenna Shovely, no date. Western History Collections, University of Oklahoma Library. 
and law-abiding citizens." Ada Faus was one of dozens who felt that during her years of service she had become a minister of sorts, reckoning that she had helped to produce countless "substantial citizens." 37

In preparation for future duties as educators, girls constantly played the role of "teacher." Sally Reeves wrote that she wrapped corncobs with paper and pretended to teach them words from a Blue Backed Spelling Book. Charlotte McGinnis exclaimed, "How I loved to ... order my imaginary pupils around and tap a bell to assist them to march!"38 As teenagers, the future teachers often had the chance actually to live out their fantasies, for country educators, faced with large ungraded classes, called on the better female students to instruct the younger children. ${ }^{39}$ The experience gained in such cases, added to the relative ease of obtaining teaching certificates, encouraged a number of the women to begin their careers on or before their eighteenth birthday.

Despite some early entries into the classroom, a sense of professional pride drove all of the women in this study for whom data is available to complete a baccalaureate degree years before Texas, Oklahoma, or Colorado required it for teacher certification. ${ }^{40}$ Moreover, 68.6 percent of the 83 Texans, half of the 308 Oklahomans, and 48.9 percent of the 98 Coloradans earned at least a master's degree; while 18 from the three states went on to obtain a doctorate. Such achievements appear to be higher than the regional norm. By the 1940s, many of the women depicted here had completed their undergraduate training or were working on an advanced degree. In 1942 in Colorado, however, 32.8 percent of the state's teachers lacked a four-year degree. In 1946 in Oklahoma, 29.3 percent of the teachers had not acquired a bachelor's degree, and even by 1948 , 18.6 percent of Texas teachers lacked that credential. $^{41}$

Alone, this impersonal degree data could, however, tell a somewhat erroneous story; for as young women, not all the teachers discussed here initially complied with their families' and teachers' prodding. A few girls were afraid to leave home at all. "Lord," Jewel Peterson remembered praying, "I wish I didn't have the intelligence to know that I need to go to college, but I do." Others who were eager to continue their education aspired to professions other than teaching, but they too eventually enrolled in the pedagogical course of study. Mary Carden explained, "I wanted to become an artist, but since I had the opportunity [to go to East Texas State Teachers College] I became a teacher." Reenacting what was for many others an almost unconscious career choice, Letha Campbell wrote rhetorically, "Who ever heard of a man taking primary teaching courses or a women majoring in engineering?" Similar testimony came from Ruth Marshall, who confessed, "In those days I did not know that [a woman] went to college for any other purpose except to become a teacher." 42

Thus, though they may have been confined to the teaching profession, the students did not believe that they were socially stigmatized, feeling honorable and expecting respect. ${ }^{43}$ That only six teachers with whom I corresponded identified any gender discrimination in their higher educational experience evidences how swiftly the domestic ideology appeared to resolve any conflict involving career choices and to complete the assimilation of the young women into the education field. Consciously manipulating the ideology, professors, counselors, and college administrators channeled women toward their accepted role as teachers. One woman identified the subtle manner in which women were "cooled out" of traditional male program areas, explaining that her Ph.D. mentor at a Texas university advised her, "'not to take this man's course [as] . . . I didn't need it.", "I went ahead, though," she continued, "and did not earn but was given a ' $\mathrm{C}$ ' in the course." $44 \mathrm{~J}$. Smith reported another case involving a friend enrolled at the University of Oklahoma "who practically fought her way into Geology School. . . . The Dean did everything he could to stop her," Smith recounted, "but she persisted, although he made her life miserable." Similarly, Texan Frances Watkins remembered that "the Dean of Women 


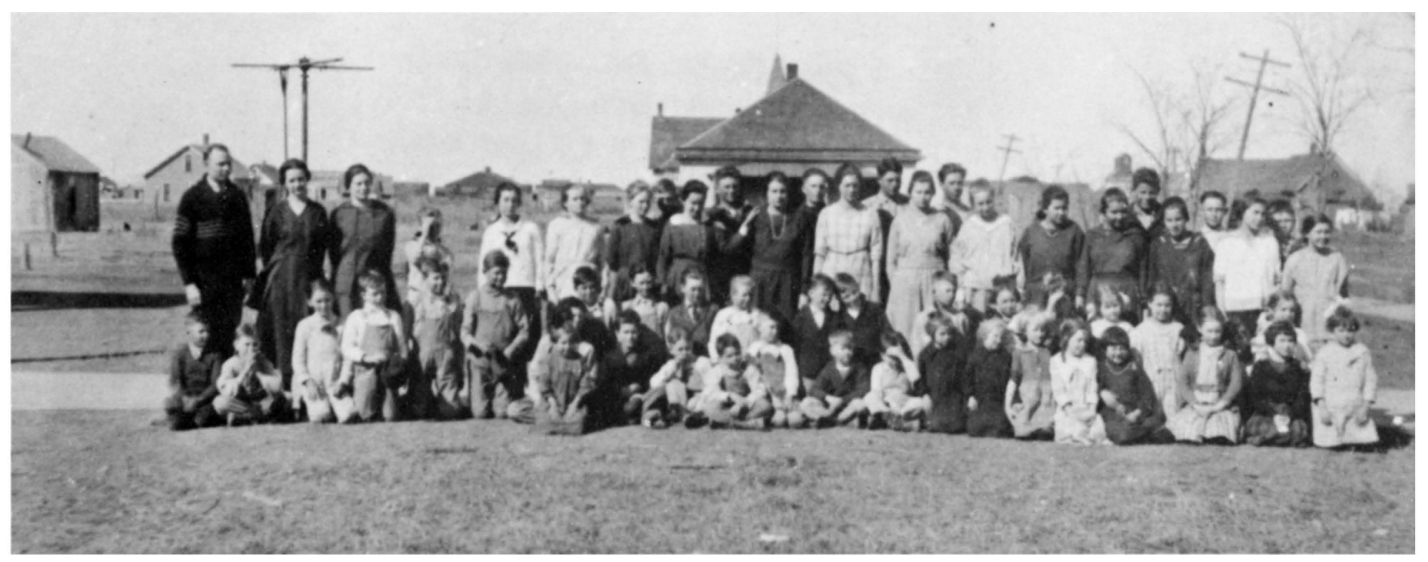

FIG. 5. School group at Avard, Oklahoma, 1921. The three adults are Mr. Roy J. Travis, principal; Mrs. Ruth M. Gaines, intermediate teacher; and Mrs. Grace I. Benefield, primary teacher. Western History Collections, University of Oklahoma Library.

was horrified that I would ... post 'A's in difficult math courses and only 'B's in English. ... [In] her words," Watkins repeated, "you may major in math, but no one will hire a woman to teach math.', 45

Looking back in 1981, Vernice Sellman tried to explain why as young college students she and her counterparts had accepted the job of teacher as their only professional alternative. "During most of my college years there was no ERA to make us conscious of any difference," Sellman recollected. ${ }^{46}$ Such a statement illustrates that at the time, or even today, she and many of her colleagues were unaware that an Equal Rights Amendment had been proposed in 1923 and that it was debated in the United States Congress almost every year thereafter. ${ }^{47}$ Given the importance of domestic ideology to a woman's teacher-training experience, however, it is understandable that as a young adult Sellman's frame of reference would have excluded a concept that threatened to dissolve the traditional social importance of the woman's role. In fact, some of the female educators defined sex discrimination in college as male disregard for their separate but hallowed station. Edna Frederick wrote with perhaps unconscious irony that she "was aware of no discrimination whatsoever," because "the men students treated us [women] with a certain gallantry." 48

As new teachers, these women entered the classroom firmly rooted in a world view that embraced separate male and female spheres, and they expected to be rewarded and acknowledged for acting out the most conservative interpretation of nineteenth-century femininity, emanating from the "cult of true womanhood."49 We considered it our "duty," explained one teacher, "to conform to [these] social ideals." When asked to wear a girdle, dry their underwear on the line in a pillowcase, stay in town at all times, go to church, teach Sunday School, say prayers over the dead, and refrain from drinking, smoking, dancing, or card playing, they usually complied, "accept[ing] and question [ing] little." 50

Because of the dearth of detailed information on how the women actually conducted their classes, it is difficult to say whether the teachers consciously perpetuated gender stereotypes among their students. Ruby McKenna, a junior high school mathematics teacher, did channel her male and female pupils into two different directions. "[A] woman mathematics teacher was best teaching in the junior high school," she stated. "Here," McKenna continued, "you could encourage girls to work in 
the field of mathematics and a man in the high school mathematics department could give the boys a more practical outlook on the subject." Gladys Hubbard also revealed her bias, writing, "I'm afraid I must admit to being just a little bit partial to the boys in my classes. Perhaps it was because they seemed more honest in their attitude toward their teachers; [if] they didn't like you, you always knew it." Conversely, the remarks of Coloradan Bertha Hume suggest that on-the-job experiences convinced some teachers to focus more on women's abilities and rights and less on their social duties. Hume reasoned that girls had just as much if not more forthrightness than boys and consequently helped a girl named Darle get elected studentbody president. Hume worked for Darle even though an administrative official asked her to talk the girl out of running. "I chuckle now at our temerity," Hume later wrote, "for Darle was elected student president and made the headlines of The Greely Tribune." 51

\section{THE STRUGGLE FOR}

\section{PROFESSIONAL RECOGNITION}

During the decades following the passage of the Nineteenth Amendment, the continued discrimination against women encouraged many teachers to become as assertive as Hume, without abandoning their belief in separate gender spheres. Because most school boards throughout the nineteenth and early twentieth centuries refused to hire married women, many females refused to marry, in order to keep their jobs. ${ }^{52}$ Mima Williams succinctly explained, "I never found a man I couldn't live without." In fact, 45.5 percent of the 121 Coloradans, 16.8 percent of the 273 Oklahomans, and 36.8 percent of the 95 Texans, for whom data is available, remained single throughout their lives. At least two widows and five divorcees from the three states reentered the classroom after a stint as housewives and never married again. In addition, a number of teachers deferred matrimony until they were thirty, forty, or even fifty years of age and purposely limited their family size so that they could maintain an uninterrupted career. On the other hand, many married women indicated that their holding a job, especially during the lean years of the 1930s, significantly altered gender stereotypes in their homes, as men and women juggled roles to keep their families together. Ora Mason explained, "I went outside [the house] and worked ... and [my husband] always helped take care of the children." Similarly, Eunice Salomonson remarked, "We had no time to consider specific roles. We were a family aiming at mutual goals, and this included our two sons." 53

At work and even in some homes, however, gender conflicts persisted, exacerbated by Depression-Era poverty and Dust-Bowl devastation in parts of the study area. Married women teachers who had been able to override the longstanding ban on their employment were fired by school boards acting on the assumption that women, especially married ones, had someone to take care of them, but that men needed work to support themselves and their families. In addition, many of the teachers, women and men, who managed to keep a teaching job during the depression often worked for discounted paychecks or, at times, literally for nothing.

During World War II, when men were in short supply, many women teachers advanced professionally. Often they were asked to assume a male administrator's post. Texan Mary Roberson became superintendent of the Hartley County school system, a responsibility and a doubling of her work load for which, however, she received no increase in pay. Even so, she liked her new position, but after the war, Roberson, and many others like her, were not allowed to keep their jobs. ${ }^{54}$ As school systems grew, administrative salaries and managerial responsibilities increased, making educational leadership positions attractive to more and more men. ${ }^{55}$ Subsequently many county superintendencies and teaching principalships, often held by women, were phased out, and males were hired to manage the new consolidated rural or expanding urban institutions. This trend reached its logical conclusion in Colorado in 1952 when the state's last elected state superintendent, a woman, stepped down to be replaced 
by the first in a series of appointed male commissioners of education. ${ }^{56}$ At mid-century, throughout the entire country, men began reclaiming high school teaching posts as well, and by 1983 they constituted a bare majority of the secondary classroom instructors. Women, on the other hand, still held almost all of the less prestigious elementary and special education positions. ${ }^{57}$ Estelle Faulconer recorded her reaction to such evolutionary developments in Oklahoma, charging, "Men were given a title so they could get more money." Donna Van Hoove responded even more vehemently, claiming that during her career, she had found "but a handful of principals . . . who were not egotistical, had a bad case of master/slave syndrome, expected women to be subservient, and generally had poor organizational skills." In a more general context, Fleta Hill also complained, "It's been my experience that many times women do the work and men get the credit!",58

Even the traditionally acquiescent female teachers, however, had a history of struggle against such discrimination. In 1914, Althea Barr Taft disrupted a meeting of the Oklahoma Education Association (OEA), exclaiming, "I want to warn you men that women teachers will not participate in another convention without being active in it and without learning for themselves what is going on." 59 Twenty-six years later many of her professional progeny joined Texas, Oklahoma, or Colorado branches of the Department of Classroom Teachers Association (DCT), founded in 1913 as an affiliate of NEA. In 1933, Muskogee teacher Kate Frank reorganized the DCT and served as president for four years, beginning in 1934. Three years later Frank became president of the OEA, going on to serve on the NEA Board of Directors and eventually holding that organization's vice-presidency. Her aggressive leadership won her a broad following and so frightened the Muskogee school board that she was fired in 1943. Frank and the OEA fought the decision, and she was reinstated in 1945. 60

During the thirties, women ACTA members from Denver successfully threatened resignations if the city's school board did not institute an equal pay scale for men and women. ${ }^{61}$ In addition, the women teachers joined other activist groups formed earlier, such as the American Association of University Women (AAUW), founded in 1881 exclusively by and for women. In Colorado, Beatrice Young supported AAUW because it promised to work for the installation of more female professors at the University of Denver. Many who joined Delta Kappa Gamma attested to their organization's consciousness-raising effects. According to Christine Kirkpatrick, the association "contributed to the well being of women teachers and enhanced their own feelings of worth ... [which] provided impetus for ... self improvement." The exchange of ideas "with other top professional educators," Joe Johnston added, "proved to be challenging and rewarding and encouraged intellectual achievement as well as recognition of academic excellence." 62

\section{POST WAR CHALLENGES TO \\ THE TRADITIONAL ROLE}

Dramatic social changes devaluing the traditional female role came in the quarter century following World War II. Afraid that their profession's philosophical base was in jeopardy, teachers held fast to their support of women's separate sphere, even as they struggled for professional recognition and status. As early as the late 1940s, Colorado teacher-educator Edith Beechel voiced concern about the diminishing numbers of young women who aspired to be teachers. She noted that many girls were attracted not to education but to the more glamorous vocations of "Secretary or Air Stewardess." 63 Beginning in the 1960s, modern feminists and scholars, some of whom intended to "liberate" women from what they perceived as the age-old domestic prison, furthered the decline in the popularity of the teaching profession by casting aspersions on all occupations associated with the maternal role. ${ }^{64}$ Both single and married women teachers observed this decline with great regret, striking back with comments such as, "the home and especially children have suffered from women not staying where 


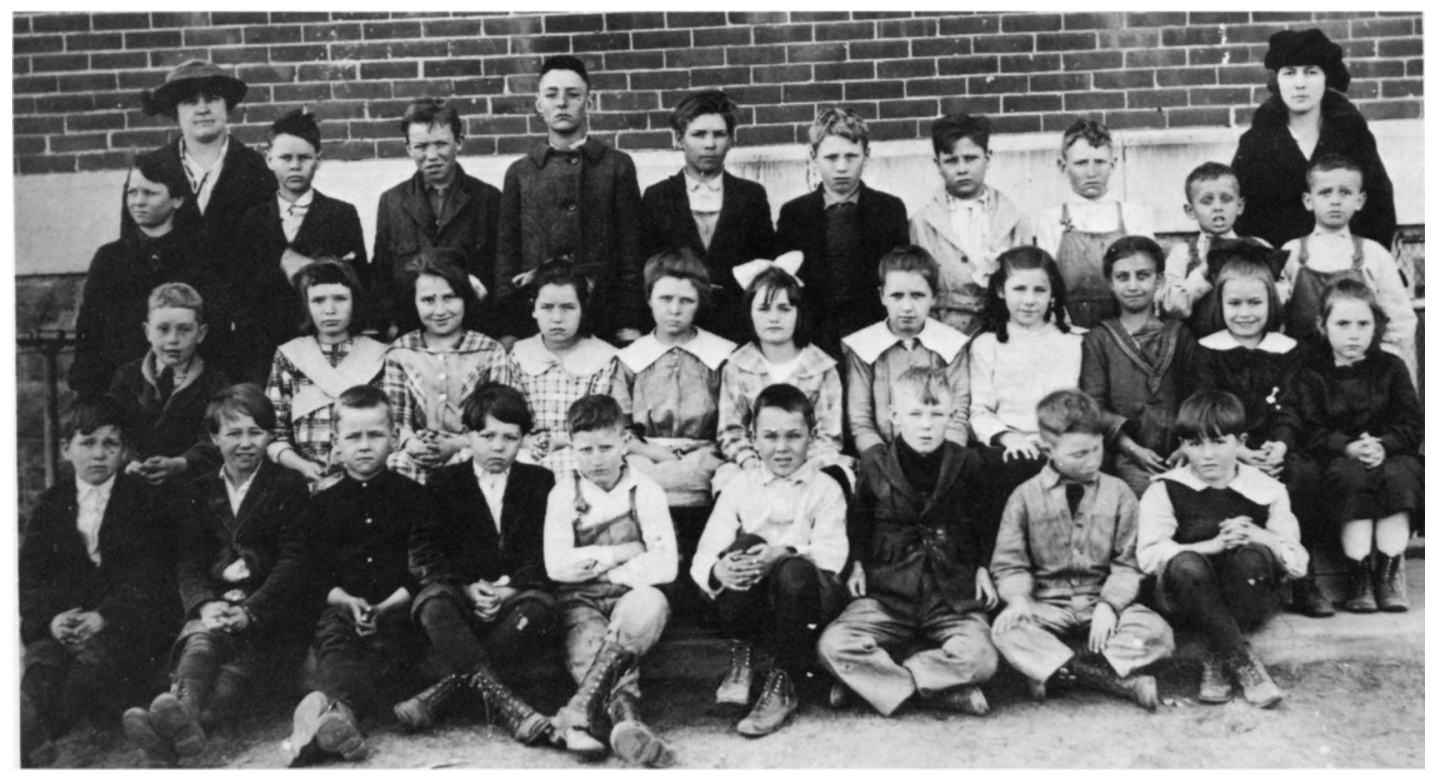

FIG. 6. Fourth grade, Kiefer, Oklahoma, 1921. Western History Collections, University of Oklahoma Library.

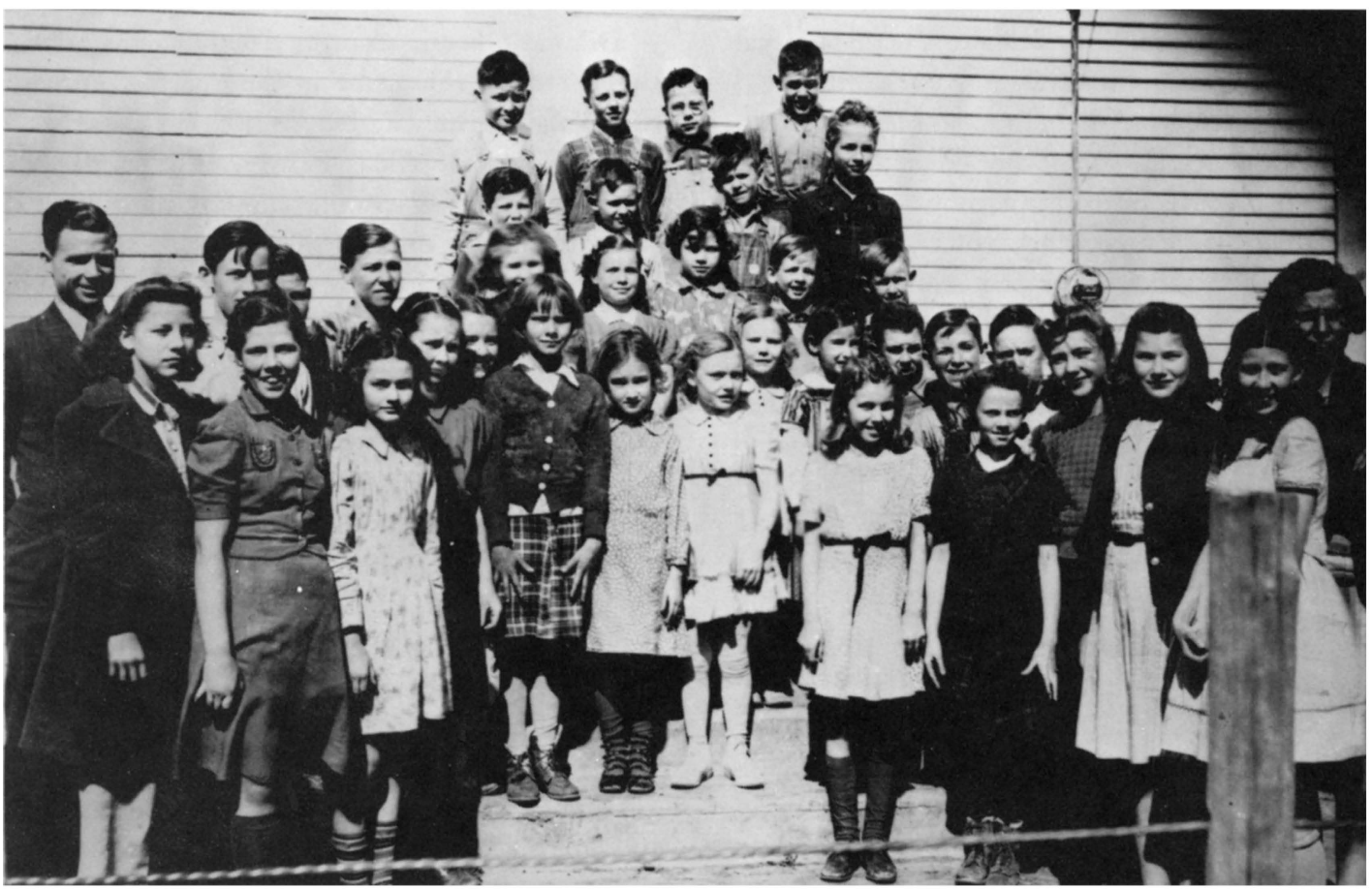

FIG. 7. Crossroads school, Paul's Valley, Oklahoma, 1938. Western History Collections, University of Oklahoma Library. 


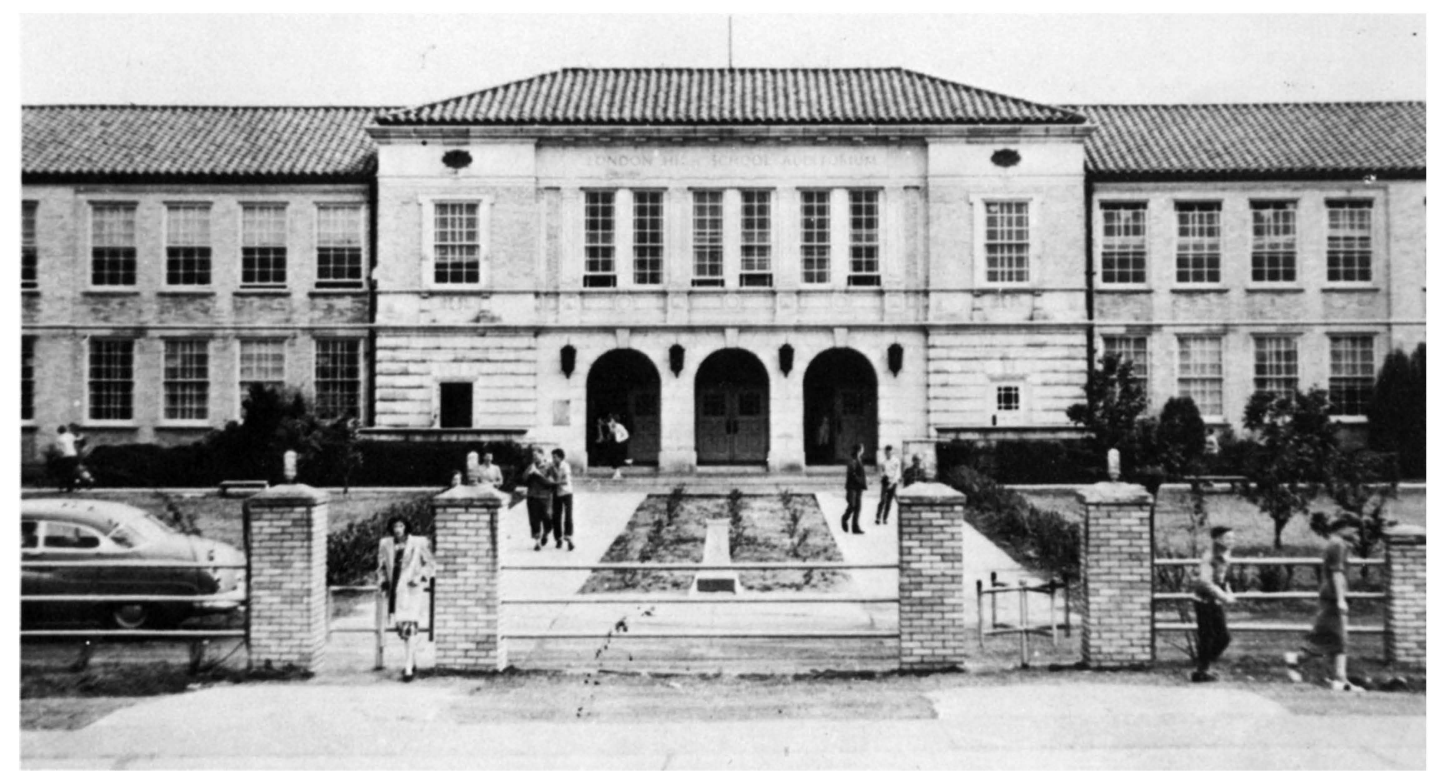

FIG. 8. New London School, New London, Texas, 1952. Western History Collections, University of Oklahoma Library.

they should," and "the liberation movement is destroying the family unit." Revealing her solution to this problem, Wilma Scott proposed:

If it is necessary for mothers to work, they [should] plan their work hours so that their children are not cheated. . . . I still believe one of the most honorable stations in life is being a good mother. Both parents must be equally interested in the education of their child, but a mother's influence is vital. ${ }^{65}$

Interestingly enough, organizations such as Delta Kappa Gamma have in recent years supported measures like the Equal Rights Amendment, which could eliminate the legitimacy of gender-linked occupations or social roles. ${ }^{66}$ of all the women with whom I corresponded, however, only about one-third could agree with the policy, and most of them had strong reservations concerning their choice. In keeping with other national associations representing women in the traditionally domestic career fields, Delta Kappa Gamma's national leadership has been more willing than the every-day practitioner to discard domestic ideology, which had been the heart of the nineteenth- and twentieth-century community-building experience. ${ }^{67}$ For instance, Louise Holler insisted, "God in His wisdom chose to make me a woman, [and] it is my choice to continue to think, behave, and react as a woman and be treated as a woman." 68 Eunice Salomonson agreed, charging:

By wanting to be mannish instead of feminine ... women have written their own ticket to defeat. Never in the history of mankind has esteem for women been so lacking. ... Women are not, at the present time, proving that they can fulfill the two roles of career and home-consequently there are too many broken homes and unsuccessful career[s] ${ }^{69}$

Selma Long had similar difficulties advocating a feminism that would lead to the dissolution of gender spheres, because, like her contemporaries, she was primarily concerned with the diminishing status of domesticity. "My husband 
[has] treated me as a partner besides being my protector; it never occurred to me that there was a need for an Equal Rights Amendment," she wrote. Only a few women teachers were willing to agree with Annie Joy, who admitted somewhat sadly that freedom from gender-role stereotypes "takes some things away, but ... it provides a great deal more than it takes." 70

Unlike Joy, the vast majority of the women in this study will never repudiate the ideology of domesticity. Their belief that women are essentially homemakers and nurturers who also have a right to put their talents to use outside the home has unquestionably caused conflict for these women, particularly for those few who as children dreamed of careers in art or engineering, or who left their parents' homes with trepidation. But the ideology that first marked out teaching as an appropriate profession for them has also irrevocably shaped their understanding of their profession and the meaning of their own lives. ${ }^{71}$ Their jobs did, after all, gain for them social approval both in the work place and in the home. More importantly, these teachers, like their predecessors, capitalized on the social support that the rhetoric of domesticity granted them to demand recognition for their professional achievements and their role as community builders. On the other hand, this generation of teachers is also to some extent bound by the rhetoric that served them. Accepting the core assumption of domesticity, that women are responsible for the maintenance of familial and social morality, they identify today's feminism with narcissism and loss of values rather than self-respect and a demand for equality. Although younger feminists may view the women in this study only as symbols of the past, these women, in their retirement, view what they perceive as the tragedies of contemporary society with a renewed belief that their own lives, securely nestled within the ideology of domesticity, have been full of purpose.

\section{NOTES}

1. For definitions of domesticity see Nancy F. Cott, The Bonds of Womanhood: Woman's
Sphere in New England, 1780-1835 (New Haven: Yale University Press, 1977), pp. 63100; Carl N. Degler, At Odds: Women and the Family in America from the Revolution to the Present (New York: Oxford University Press, 1980), p. 327; Mary P. Ryan, Cradle of the Middle Class: The Family in Oneida County, New York, 1780-1865 (New York: Cambridge University Press, 1981), pp. 60-229; Kathryn Kish Sklar, Catharine Beecher: A Study in American Domesticity (New Haven: Yale University Press, 1973), pp. 122-67.

2. For work on teaching as part of the female life cycle see David F. Allmendinger, Jr., "Mount Holyoke Students Encounter the Need for Life Planning, 1837-1850," History of Education Quarterly 19 (Summer 1979): 27-46; R. M. Bernard and Maris A. Vinovskis, "The Female School Teacher in Ante-Bellum Massachusetts," Journal of Social History 10 (Spring 1977): 332-45. Some historians have emphasized the limitations of traditional education for women. For examples see Jill Conway, "Perspectives on the History of Women's Education in the United States," History of Education Quarterly 14 (Spring 1974): 1-12; Roberta Wein, "Women's Colleges and Domesticity, 1875-1918," History of Education Quarterly 14 (Spring 1974): 31-42; Keith Melder, "Mask of Oppression: The Female Seminary Movement in the United States," New York History 55 (July 1974): 261-79; Phillida Bunkle, "Sentimental Womanhood and Domestic Education, 1830-1870," History of Education Quarterly 14 (Spring 1974): 13-30. On the antiintellectualism of women teachers see Redding Sugg, Jr., Motherteacher: The Feminization of American Education (Charlottesville: University of Virginia Press, 1978), pp. 160-81; Patricia C. Sexton, "Schools Are Emasculating Our Boys," in And Jill Came Tumbling After: Sexism in American Education, ed. Judith Stacy, Susan Bergland, and Joan Daniels (New York: Dell, 1974), pp. 139-41. For sociological works on the semiprofessional status of teaching because of women's numerical domination of classroom posts refer to George Ritzer, Man and His Work: Conflict and Change (New York: Appleton-Century Crofts, 1972), p. 205; Theodore Leggatt, "Teaching As a Profession," in Professions and Professionalization, ed. J. A. Jackson (London: Cambridge University Press, 1970), p. 165; Richard L. Simpson and Ida 
Harper Simpson, "Women and Bureaucracy in the Semi-professions," in The Semi-Professions and Their Organization, ed. Amati Etzioni (New York: Free Press, 1969), p. 231; Talcot Parsons, "Implications of the Study," in The Climate of Book Selection: Social Influence on School and Public Libraries, ed. I. Periam Danton (Berkeley: University of California School of Librarianship, 1959), p. 94; Louis H. Orzack, "Work As a 'Central Life Interest' of Professionals," Social Problems 7 (Fall 1959): 125-32; Dan C. Lortie, Schoolteacher: A Sociological Study (Chicago: University of Chicago Press, 1975), pp. 83-108.

3. See Polly Kaufman, Women Teachers on the Frontier (New Haven: Yale University Press, 1984), pp. 1-65; Jacqueline Jones, "Women Who Were More Than Men: Sex and Status in Freedmen's Teaching," History of Education Quarterly 19 (Spring 1979): 47-60; Anne Firor Scott, "The Ever Widening Circle: The Diffusion of Feminist Values From Troy Female Seminary, 1822-1872," History of Education Quarterly 19 (Spring 1979): 3-25; Nancy Hoffman, Woman's "True" Profession: Voices from the History of Teaching (Old Westbury, N.Y.: Feminist Press, 1981), pp. 200-16.

4. Mary Kelley, "At War with Herself: Harriet Beecher Stowe as Woman in Conflict within the Home," in Woman's Being, Woman's Place: Female Identity and Vocations in American History, ed. Mary Kelley (Boston: G. K. Hall, 1979), pp. 201-15; Sklar, Catharine Beecher, pp. 204-5; Courtney Ann VaughnRoberson, "Sometimes Independent But Never Equal-Women Teachers, 1900-1950: The Oklahoma Example," Pacific Historical Review 53 (February 1984): 39-58.

5. For another largely descriptive work on edited excerpts from the letters of retired teachers from Oklahoma see James Smallwood, And Gladly Teach (Norman: University of Oklahoma Press, 1976).

6. Vaughn-Roberson, "Sometimes Independent But Never Equal,” pp. 39-58. This work analyzes both minority and white women teachers in the twentieth century.

7. Linda K. Kerber, "Daughters of Columbia: Educating Women for the Republic, 17871805," in Our American Sisters: Women in American Life and Thought, ed. Jean E. Fried- man and William G. Shade (Lexington, Mass.: D. C. Heath, 1982), pp. 134-53; Mary Beth Norton, Liberty's Daughters: The Revolutionary Experience of American Women, 17501800 (Boston: Little, Brown, 1980), pp. 19798, 256-65; Debora Fitts, "Una and the Lion: The Feminization of District School-Teaching and Its Effects on the Roles of Students and Teachers in Nineteenth-Century Massachusetts," in Regulated Children, Liberated Children: Education in Psychohistorical Perspective, ed. Barbara Finkelstein (New York: Psychohistory Press, 1979), pp. 140-57.

8. Ryan, Cradle of the Middle Class, pp. 60 229.

9. Sklar, Catharine Beecher, pp. 122-37; Elizabeth Alden Green, Mary Lyon and Mount Holyoke: Opening the Gates (Hanover, N.H.: University Press of New England, 1979), pp. 105-10; Thomas Woody, A History of Women's Education in the United States, vol. 1 (New York: Octagon Books, 1980), 1:460-518.

10. Barbara M. Cross, ed., The Educated Woman in America: Selected Writings of Catharine Beecher, Margaret Fuller, and M. Carey Thomas (New York: Teachers College Press, 1965), p. 109. Also see Robert N. Hudspeth, ed., The Letters of Margaret Fuller (Ithaca: Cornell University Press, 1983), pp. 36-39.

11. Burton J. Bledstein, The Culture of Professionalism: The Middle Class and the Development of Higher Education in America (New York: W. W. Norton, 1976), pp. 80-128.

12. For information on teachers, nurses, clubwomen, reformers, or social workers see Hoffman, Woman's "True" Profession, pp. 200-16; Barbara Melosh, The Physician's Hand: Work Culture and Conflict in American Nursing (Philadelphia: Temple University Press, 1982); Karen J. Blair, The Clubwoman As Feminist: True Womanhood Redefined, 1868-1914 (New York: Holmes \& Meier Publishers, 1980); Estelle Freedman, "Separation As Strategy: Female Institution Building and American Feminism, 1870-1930," Feminist Studies 5 (Fall 1979): 512-29; Blanche Wiesen Cook, "Female Support Networks and Political Activism: Lillian Wald, Crystal Eastman, Emma Goldman," in A Heritage of Her Own, pp. 41244.

13. On the subordination to male authority 
see John Mack Faragher, Women and Men on the Overland Trail (New Haven: Yale University Press, 1979); Lillian Schlissel, Women's Diaries of the Westward Journey (New York: Schocken: Books, 1982); Marion S. Goldman, Gold Diggers and Silver Miners: Prostitution and Social Life on the Comstock Lode (Ann Arbor: University of Michigan Press, 1981).

14. Julie Roy Jeffrey, Frontier Women: The Trans-Mississippi West, 1840-1880 (New York: Hill \& Wang, 1979), pp. 179-99; Mary P. Ryan, Cradle of the Middle Class, pp. 105-44.

15. Ryan, Cradle of the Middle Class, p. 234.

16. Sklar, Catharine Beecher, p. 180.

17. Aileen S. Kraditor, The Ideas of the Woman Suffrage Movement, 1890-1920 (New York: W. W. Norton, 1981), pp. 4-5.

18. David Tyack and Elizabeth Hansot, Managers of Virtue: Public School Leadership in America, 1820-1980 (New York: Basic Books, 1982), p. 187.

19. William B. Faherty, "Regional Minorities and the Woman Suffrage Struggle," Colorado Magazine 33 (July 1956): 212-17; Billie Barnes Jensen, "Colorado Woman Suffrage Campaigns of the 1870s," Journal of the West 12 (April 1973): 254-71; Jensen, "Let the Women Vote," Colorado Magazine 41 (Winter 1964): 13-25.

20. Edwin I. Grenfell, A Brief Sketch of the Life and Works of Helen Thatcher Loring Grenfell (Denver: Smith-Brooks Printing Co., 1939): pp. 12-59, 75-87; Delta Kappa Gamma, Torchbearers: Biographical Sketches of Colorado Women Educators (Boulder: Johnson Publishing Co., 1967), p. 69. For the founding of NEA see Joan N. Burstyn, "Historical Perspectives on Women in Educational Leadership," in Women in Educational Leadership, ed. Sari Knopp Biklen and Marilyn B. Brannigan (Lexington, Mass.: D. C. Heath, 1980), p. 69.

21. Tyack and Hansot, Managers of Virtue, p. 180.

22. Delta Kappa Gamma, Torchbearers, pp. 78-79; biographical sketch of Mary Bradford, Delta Kappa Gamma Collection, Ruth Hardiman home, Denver, Colorado, hereafter cited as DKGC.

23. Helen Grenfell, quoted in Grenfell, $A$ Brief Sketch, pp. 17, 19.

24. Louise Boyd James, "Woman's Suffrage Oklahoma Style, 1890-1918," in Women in Oklahoma: A Century of Change, ed. Melvena
Thurman (Oklahoma City: Oklahoma Historical Society, 1982), pp. 182-83; James, "The Woman Suffrage Issue in the Oklahoma Constitutional Convention," Chronicles of Oklahoma 56 (Winter 1979): 379-92.

25. Jim Pearson and Edgar Fuller, Education in the States: Historical Development and Outlook (Washington, D.C.: National Education Association of the United States, 1969), p. 979.

26. James, "The Woman Suffrage Issue," pp. 379-92.

27. Ruth Moore Stanley, "Alice M. Robertson: Oklahoma's First Congresswoman," Chronicles of Oklahoma 45 (Autumn 1967): 25989; Joe Hubbell, "Women in Education," in Women in Oklahoma, pp. 149-50.

28. Alice Robertson, quoted in a newspaper article, Alice Robertson Collection, Oklahoma Historical Society, Oklahoma City.

29. Elizabeth Taylor, "The Woman Suffrage Movement in Texas," Journal of Southern History 17 (May 1951): 194-215.

30. Annie Webb Blanton, A Hand Book of Information (Austin: State Department of Education, 1923), pp. 57-59.

31. Ralph Lewis Lynn, "The Educational Points of View and Services of the Texas State Superintendents of Public Instruction" (M.A. thesis, Baylor University, 1946), pp. 148-59.

32. Delta Kappa Gamma, Our Golden Anniversary (Austin: Delta Kappa Gamma, 1979), p. 4.

33. Grace C. Strachan, quoted in Hoffman, Woman's "True" Profession, p. 298. For more on teacher unionization see Wayne Urban, "Organized Teachers and Educational Reform during the Progressive Era: 1890-1920," History of Education Quarterly 16 (Spring 1976): 35-52.

34. Biographical sketch of Minnie Schroter, DKGC.

35. Biographical sketch of Christine Kirkpatrick, Iota Chapter of Delta Kappa Gamma, in Personalities (Denton, Tex.: Delta Kappa Gamma, 1980), p. 46; Opal Scales correspondence, 1976, Oklahoma Retired Teachers Association Letters, Oklahoma Historical Society, Oklahoma City, hereafter cited as ORTL.

36. "Allie Smith Collins: Wife, Mother, Teacher," Amarillo Daily News, 20 November 1982, p. 4-B.

37. Eleanor Reser correspondence, 1976, ORTL; Zelma Farris correspondence, 1976, 
ORTL; biographical sketch of Ada Faus, Torchbearers, pp. 109-10.

38. Biographical sketch of Sallie Reeves, DKGC; Torchbearers, pp. 166-67; biographical sketch of Charlotte H. McGinnis, DKGC.

39. Interview with Frances and George Wheeler, Spring 1978, Colorado Oral History Project No. 1894, Steamboat Springs High School, Steamboat Springs, Colorado.

40. Fuller and Pearson, Education in the States, p. 394. Though the legislatures of Texas, Oklahoma, and Colorado passed laws throughout the first half of the twentieth century requiring some college course work for certification, not until 1955, 1957, and 1961, respectively, did each state require the bachelor's degree.

41. Thirty-Third Biennial Report of the State Superintendent of Public Instruction of the State of Colorado (Denver: State Department of Education, 1943), pp. 108, 110-12; TwentySecond Biennial Report of the State Department of Education of Oklahoma (Oklahoma City: State Board of Education, 1948), pp. 241; Cecil Eugene Evans, The Story of Texas Schools (Austin: Steck, 1955), p. 409. Though the diminishing numbers of qualified men and women during the World War II years probably influenced these state statistics, the 1940s were a time of professionalization for many of the women portrayed in this paper.

42. Jewell Peterson, correspondence with the author, Summer 1981; Mary Carden, quoted in Personalities, p. 8; Letha Campbell, correspondence with the author, Summer 1981; Ruth Marshall, quoted in Personalities, p. 57.

43. For a classic work on the sociological concept of "stigma" see Erving Goffman, Stigma: Notes on the Management of Spoiled Identity (Englewood Cliffs, N.J.: Prentice-Hall, 1963). Other sources on the subject include Richard D. Schwartz and Jerome H. Skolnick, "Two Studies of Legal Stigma," in The Other Side, ed. Howard S. Becker (New York: Free Press, 1964), pp. 103-17.

44. For reference to "cooling-out" see Burton R. Clark, "The Cooling-Out Function in Higher Education," American Journal of Sociology 65 (May 1960): 65-70; quotation from an anonymous source, correspondence with the author, Summer 1981.

45. J. Smith, correspondence with the author,
Summer 1981; Frances Watkins, correspondence with the author, Summer 1981.

46. Vernice Sellman, correspondence with the author, Summer 1981.

47. Carl N. Degler, At Odds: Women and the Family in America, pp. 359, 403, 446-48; Nancy F. Cott, "Feminist Politics in the 1920s: The National Woman's Party," Journal of American History 71 (June 1984): 43-68.

48. Edna Frederick, correspondence with the author, Summer 1981.

49. Barbara Welter, "The Cult of True Womanhood: 1820-1860," American Quarterly 18 (Summer 1966): 151-74.

50. Nettie Witever, correspondence with the author, Summer 1981; Katherine Moore correspondence, 1976, ORTL. The list of requirements is taken from the testimonies of numerous women teachers.

51. Ruby McKenna, correspondence with the author, Summer 1981; biographical sketch of Gladys Hubbard, in Torchbearers, pp. 95-96; Bertha Dorre Hume, correspondence with the author, Summer 1981.

52. Degler, At Odds: Women and the Family in America, p. 412; David Tyack and Myra Strober, "Men and Women in the Schools: Toward a History of the Sexual Structuring of Educational Employment," unpublished paper in the author's possession.

53. Mima Williams, correspondence with the author, Summer 1981; Ora Cornelison Mason, interview, 18 May 1979, Colorado Oral History Project, Fort Collins Public Library; Eunice Salomonson, correspondence with the author, Summer 1981.

54. Mary Roberson, interview by the author, Spring 1981.

55. H. Warren Button and Eugene F. Provenzo, Jr., History of Education and Culture in America (Englewood Cliffs, N.J.: Prentice-Hall, 1983), pp. 215-62.

56. Ruth Hardiman, interview by the author, Summer 1981.

57. Emily C. Feistritzer, A Carnegie Foundation Technical Report (Princeton: Carnegie Foundation for the Advancement of Teaching, 1983), pp. 35, 38. For data on the declining numbers of female public school administrators see Joyce Payne, "Black Women in Urban Schools," in Women and Men: The Consequences of Power, ed. Dana V. Hiller and Robin 
Ann Sheets (Cincinnati: Office of Women's Studies, University of Cincinnati, 1976), pp. 196-211. For documentation of the gradual gender segregation and decline of women in higher education see Rosalind Rosenberg, Beyond Separate Spheres: Intellectual Roots of Modern Feminism (New Haven: Yale University Press, 1983), pp. 238-46.

58. Estelle Faulconer, correspondence with the author, Summer 1981; Donna Van Hoove, correspondence with the author, Summer 1981; Fleta M. Hill correspondence, 1976, ORTL.

59. Althea Barr Taft, quoted in Hubbell, "Women in Education," in Women in Oklahoma, p. 151.

60. Hubbell, "Women in Education," in Women in Oklahoma, p. 153; Kate Frank, interview, 2 November 1974, Oklahoma Historical Society Living Legends Project, Oklahoma Historical Society, Oklahoma City.

61. Marian Bullesel, correspondence with the author, Summer 1981; Imogene Springer, correspondence with the author, Summer 1981; Ruth Hardiman, interview, 1981; Viola Krig, correspondence with the author, Summer 1981.

62. Beatrice Young, correspondence with the author, Summer 1981; biographical sketch of Christine Kirkpatrick, in Personalities, p. 46; biographical sketch of Joe Johnston, in Personalities, p. 46.

63. Edith E. Beechel, "The Challenge of the Future," 23 March 1946, box 1, no. FF11, Edith E. Beechel Collection, Western History Department, Denver Public Library, Denver.

64. For examples of work that devalued the traditional female sphere see Betty Friedan, The Feminine Mystique (New York: Dell, 1974); Judith M. Bardwick and Elizabeth Douvan,
"Ambivalence: The Socialization of Women," in Readings on the Psychology of Women, ed. Judith M. Bardwick (New York: Harper and Row, 1972), pp. 52-58; Matina Horner, "Femininity and Successful Achievement: A Basic Inconsistency," in Feminine Personality and Conflict, ed. Judith Bardwick et al. (Belmont, Calif.: Brooks-Cole, 1970), pp. 45-74; Cynthia Fuchs Epstein, Woman's Place: Options and Limits in Professional Careers (Berkeley: University of California Press, 1970), pp. 23-24, $52-53,134-42$. These sources are quoted and refuted in Patricia N. Feulner, Women in the Professions: A Social Psychological Study (Palo Alto, Calif.: R. \& E. Research Associates, 1979), p. 68. For more sources refer to n. 2.

65. Alberta Hamilton, correspondence with the author, Summer 1981; Myrtle Moore correspondence, 1976, ORTL; Wilma Scott, correspondence with the author, Summer 1981.

66. Ruth Hardiman, interview by the author, Summer 1981.

67. Barbara Melosh, The Physician's Hand, pp. 3-35.

68. Louise Holler, correspondence with the author, Summer 1981.

69. Eunice Salomonson, correspondence with the author, Summer 1981.

70. Selma Long, correspondence with the author, Summer 1981; Annie Catherine Joy, correspondence with the author, Summer 1981.

71. For a discussion of ideology and institutions see Clifford Geertz, "Ideology as a Cultural System," in Ideology and Discontent, ed. David Apter (New York: Free Press of Glencoe, 1964).

The author would like to thank Robert Griswold and Glenda Riley for their insights and support. 